\title{
Effects of Artisanal Refinery on the Environment, Public Health and Socio-Economic Development of Communities in the Niger Delta Region
}

\author{
P. Ikezam \\ Department of Geography and Environmental Management \\ Faculty of Social Sciences, University of Port Harcourt, Nigeria \\ E. I. Elenwo \\ Department of Geography and Environmental Management \\ Faculty of Social Sciences, University of Port Harcourt, Nigeria

$$
\text { C. U. Oyegun }
$$ \\ Department of Geography and Environmental Management \\ Faculty of Social Sciences, University of Port Harcourt, Nigeria
}

Received: July 14, 2021 Accepted: July 28, 2021 Published: August 11, 2021

doi:10.5296/emsd.v10i3.18921ＵRL: https://doi.org/10.5296/emsd.v10i3.18921

\begin{abstract}
Nigeria discovered crude oil in 1956. Instead of making sustainable economic progress since, the country spiraled into serious economic waste and loss, due to pollution from crude oil, corruption, neglect of the oil producing regions and high handedness of the IOCs/NOCs. Today, not only are legitimate oil exploration pipelines leaking oil into the environment, illegal artisanal refineries are contributing to pollution problems and by extension economic and health effects. This study thus investigated, effects of artisanal refinery on the environment, public health and socio-economic development of communities in the Niger Delta Region. The cross-sectional research design was used in this study. The target population comprised of illegal bunkering/artisanal refining sites and households that dwell within the artisanal refinery sites. The Taro Yamane formula was used to determine the sample sizes for state and 400 was realized for each state. 1324 artisanal refining sites were
\end{abstract}


determined and using Taro Yamane equation 313 sites were derived. The Kruskal-Wallis H test was used for data analysis. The study found that, locals complained about how artisanal refineries affected their environment, health and economics. These effects varied spatially based on the result of the Kruskal Wallis test at $\mathrm{P}<0.05$. However, some of the locals identified that, despite the environmental pollution because of illegal artisanal refining in the area, some economic gains abound. It is therefore the position of this study that artisanal refining be improved, so that the environmental and health effects be reduced, while making room for sustainable economic development.

Keywords: Artisanal-refineries, Pollution, Socio-economics, Health-effects

\section{Introduction}

The presence of crude oil in Nigeria has been noticed since the year 1956 and commercial quantities for export were produced 3 years later (Agoha, 2019; Akpan-Idio, Ibrahim \& Udo, 2012). Since then the country has prided itself as one of the major producers of crude oil in the world (Albert, Amaratunga \& Haigh, 2018). Sadly, the progress made so far in the oil industry of the country, does not reflect in socio-economic development and progress of the county, nor does it reflect in the environments. Vegetation degradation pervades in the area, same can be said for soil (Amangabara \& Njoku, 2012) and water (Atubi, 2015). The consequences of these are reduction in farm lands, creation of food insecurity, bush fires, health problems for locals (Nkemakolem, 2018; Nwaejije, Hamidu \& Obiosio, 2017).

Also documented is that the government of the country have been unable to provide the finished products of crude oil (Diesel, Kerosene, fuel, gas etc) to the locals (Ayeni, 2019). Thus, the country (Nigeria) still spends humongous amounts in purchase and subsidies of refined fuel products (Anejionu, Ahiarammunnah, \& Nri-ezedi, 2015). The environments from which crude is mined (Niger Delta region), has been so polluted, that, the traditional economic activities of the locals (fishing and farming) have changed, due to pollution. Added to this problem is government's rascality in management of accrued income from crude oil and a lack of development of the oil producing areas over the years. These problems have caused serious rebellion among some of the locals in the Niger Delta region. The result is, braking the pipelines, siphoning crude oil and refining crude locally in the regions (Barenboim, Borisov, Golosov \& Saveca, 2015), albeit with many health and environmental challenges.

It is important to evaluate these environmental challenges associated with artisanal refining and crude spills from time to time, so that, the ragtag reports of the government agencies monitoring the environment, wont sway public opinion off the problems of crude oil pollution and environmental effects of artisanal refining in the study area. Till date artisanal refining is illegal in the country. Yet, it is common to find products from artisanal refineries in the Niger Delta region (Brakstad, Lofthus, Ribicic, \& Netzer 2017). This is happening because, locals find a way to bribe the authorities saddled with responsibilities to monitor the pipelines and crude oil of the nation (Chen, Zhang, Wang, \& Xu, 2020; Chikere \& Fenibo, 2018). However, the refineries of the county don't refine crude currently, due to lack of impetus by government to confront corruption in the oil industry. Therefore, it is common to 


\section{Macrothink}

see vast lands polluted by crude oil and artisanal refining activities. Today, the pollution problems have reached near irreparable heights (Dominic, 2016; Elenwo \& Urho, 2017). Water, land and air is polluted (Coderoni \& Perito, 2020). The cases of pollution related health problems have increased. Surface and underground water sources are polluted, thus leading to serious water poisoning (Bebeteidoh, Pazouki, \& Norman, 2020; Beshiru, Okareh, Chigor, \& Igbinosa, 2018). The sad reality is the products from artisanal refining augments the ones government import, albeit, with many environmental challenges. It is evident that several studies have looked at the problems of crude oil pollution on the environment (Brakstad, Lofthus, Ribicic, Netzer, 2017); however, it is important to continue to investigate the effects of artisanal refining on the environment, health and socio-economic gains or loss. This is the reason for carrying out this study.

\section{Materials and Methods}

The Niger Delta Region sits directly on the Gulf of Guinea in the Atlantic Ocean (Atubi, 2015). It comprises of nine states which include all six states of the South-South region of Nigeria (Rivers, Bayelsa, Delta, Edo, Akwa-Ibom and Cross-Rivers) and others, such as, Ondo, Abia and Imo all of which are oil producing states except Cross-Rivers State. The present-day Niger Delta covers a mass of $70,000 \mathrm{~km}^{2}(27,000 \mathrm{sq} \mathrm{mi})$ and make up $7.5 \%$ of Nigeria's land mass (figure 1). It was originally comprised of three states Rivers, Bayelsa and Delta States before its political definition in the year 2000 by the Nigerian Government. The area stretches within Latitude $4^{0} 12^{\prime} 30.892$ 'N through Latitude $4^{0} 50^{\prime} 10.7^{\prime \prime} \mathrm{N}$ and Longitude $4^{0} 56^{\prime} 15^{\prime \prime}$ E through longitude $9^{0} 40$ ' 2.654'E.

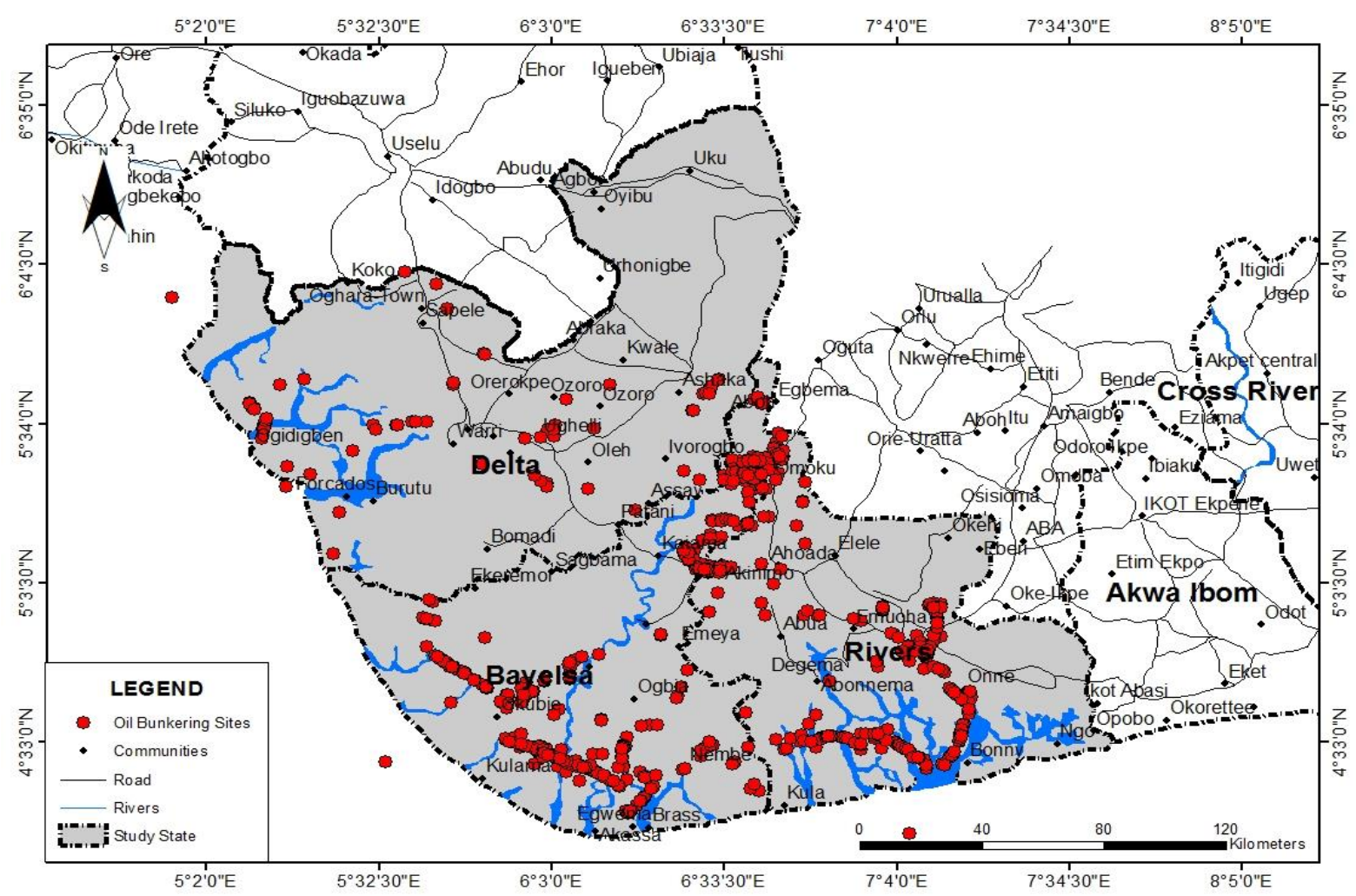

Figure 1. South-South Artisanal Oil Refining Sites 


\section{$\triangle$ Macrothink}

The Niger Delta is bounded by the Atlantic Ocean separated by the barrier island ridges bordering the Atlantic Ocean falling within the classification of a generally low-lying terrain consisting of unconsolidated mud and sandy particles resulting in little or no resistance to tidal and wave impact on its shoreline (Anifowose, Lawler, van der Horst, \& Chapman, 2014; Asimiea \& Omokhua, 2013). This partly makes it difficult to police the area and allows for criminals to steal crude oil for artisanal refining.

The monthly rainfall in the region is almost predictable following a temporal sequence of increase towards July - August before decreasing in the Dry season months of November to Feburary, rainfall is at its peak in July and September with little dry season in August (Anifowose et al., 2014). Mean temperature ranges between $27^{\circ} \mathrm{C}$ and $30^{\circ} \mathrm{C}$.

The region plays host to several multinational firms which are either petroleum or non petroleum related in business and depends largely on the aquatic resources of the coastal environment (Agoha, 2019). Crude oil was discovered in commercial quantity in 1956. Since then, the oil sector has emerged as the mainstay of the Nigeria economy. This has resulted in continued depletion of the mangrove ecosystem in the region which is said to be the largest in Africa and second largest in the world (Akpan-Idio, Ibrahim, \& Udo, 2012). Hitherto, the Niger Delta Environment was a very rich and fertile environment with diverse wetland vegetation (Beshiru et al., 2018). In addition, the environment was rich in vast deposit of oil and gas. It is the presence of crude oil in the region, which ought to be added advantage to the socio-economic progress of the region, that has surprisingly become a major source of environmental degradation, due to government neglect and the presence of artisanal refineries in the region.

This study adopted the cross-sectional research design. The target population comprised of all illegal bunkering / artisanal refining sites and households that dwell within the artisanal refinery sites. In all a total of one thousand three hundred and twenty-four (1324) artisanal refineries were enumerated. On the other hand, a total of 1184757 households were determined in Rivers State, 674424 households in Delta State and 439172 households in Bayelsa State. To determine the household for each state, the household size as determined by the Nigerian population commission (2006), which stipulates 5 persons per house hold, was used. This means that the total population of each of the affected local government was divided by 5 .

The Taro Yamane formula was used to determine the sample sizes for each state. Hence, each state had a sample size of 400 each. The research instrument was administered on 400 heads of households in each study state within the study area. Conversely, the artisanal refineries were enumerated, and 1324 sites were determined. The Taro Yamane equation (equation 1) was again deployed and a sample size of artisanal sites were derived (313) as presented in Appendix A. To avoid bias, the determine Taro Yamane sample was proportionally distributed both for the artisanal refineries and the household sizes. 
The Taro Yamane formula is as follows:

$$
\mathrm{n}=\frac{N}{1+N(e)^{2}}=\frac{1324}{1+1324(0.05)^{2}}=307
$$

where: $\mathrm{n}=$ sample size

$$
\begin{aligned}
\mathrm{N} & =\text { Population size (owners of artisanal refineries) } \\
1= & \text { Constant } \\
\mathrm{e}= & \text { error limit or margin of error or level of significance (accepted error set at } 5 \% \text { i.e. } \\
0.05) &
\end{aligned}
$$

Table 1. Artisanal Refining sites across the states

Source: Researcher's Field Work, 2020

\begin{tabular}{|l|l|l|}
\hline States & Number of Artisanal Refining & Sample Size \\
\hline Rivers & 521 & 123 \\
\hline Bayelsa & 721 & 171 \\
\hline Delta & 82 & 19 \\
\hline Total & 1324 & 313 \\
\hline
\end{tabular}

The data for the study were obtained from primary and secondary sources. The primary source of data was both quantitative and qualitative and included structured and unstructured questionnaires. The research instrument was validated by face and content validation. The instrument was tested for reliability using a test-retest approach of 30 respondents from the study area with the aid of Pearson's Product Moment Correlation coefficient. The research instrument was tested for reliability using a test-retest approach of 30 respondents from study area. A reliability coefficient of 0.84 was obtained, for both samples, indicating its reliability for the study. The data analysis was achieved using the Kruskal Wallis H test. This was used to test the hypothesis "effects of artisanal refinery on the environment, public health and socio-economic development do not significantly vary spatially.

\section{Results}

The effects of artisanal refineries on the environment of the study area is presented in table 2 . Conspicuous in the table is that all aspects of the environment have been affected by the activities of artisanal refineries. Most respondents (84\%) agreed that artisanal refineries have reduced the farm lands in the area, $15 \%$ disagree that artisanal refinery has reduced farm lands and reduced harvest, while $1 \%$ is undecided. This finding agrees with that of Chen, et al, (2020). Also, $73 \%$ of the respondents agreed that the activities of artisanal refineries have reduced the number of persons involved in fishing and farming in the area, while $21 \%$ of the respondents disagreed and $1 \%$ of them is undecided. Although $83 \%$ of the respondents agree that activities of the local refiners have improved the standard of living in the communities. Most of the respondents (78\%) agreed that the activities of artisanal refineries have reduced the number of crop and trees in the area, $21 \%$ disagreed, while $1 \%$ were undecided. Brakstad, et al, (2017), averred that, not only does the spills from the crude methods of artisanal refineries affect land productivity and render crops unproductive, but also the process of 


\section{Ml Macrothink}

artisanal refining include deforestation, thus reduces species of plants in the forests. Most respondents (78\%) agree that major source of water supply is polluted by crude oil waste from local refineries, $19 \%$ of the respondents disagree and $2 \%$ were undecided. The activities of local refining have also been identified to affect the air quality in the study area. Most respondents (83\%) suggested that the air quality in the study area is affected always by the activities of the artisanal refiners in the area, $14 \%$ disagreed while $3 \%$ is undecided. Obviously, the locals are suffering from incidences of air pollution in the area. It is also lucid that air pollution from the activities of the artisanal refineries affect the quality of air they breathe there $(72 \%)$. The species of fishes have also reduced. This assertion is agreed to by $72 \%$ of the locals.

Table 2. Effects of Artisanal Refining on the Environment

\begin{tabular}{|c|c|c|c|c|c|c|c|c|}
\hline Effect of Local Crude Refining on the Environment & $\mathbf{S A}$ & $\mathbf{A}$ & D & SD & UND & Total & WA & Decision \\
\hline \multirow{2}{*}{$\begin{array}{l}\text { Local refining activities have affected my } \\
\text { community farm lands in reduced harvest }\end{array}$} & 494 & 472 & 125 & 40 & \begin{tabular}{|l|l|l}
9 & -1 \\
\end{tabular} & 1140 & 4.22 & Agree \\
\hline & $43 \%$ & $41 \%$ & $11 \%$ & $4 \%$ & $1 \%$ & 100 & & \\
\hline \multirow{2}{*}{$\begin{array}{l}\text { Activities of the local refiners have the number } \\
\text { of persons involved in fishing and farming }\end{array}$} & 532 & 294 & 195 & 52 & 67 & 1140 & 4.02 & Agree \\
\hline & $47 \%$ & $26 \%$ & $17 \%$ & $4 \%$ & $6 \%$ & 100 & & \\
\hline \multirow{2}{*}{$\begin{array}{l}\text { Activities of the local refiners have improved the } \\
\text { standard of living in my community }\end{array}$} & 478 & 463 & 113 & 56 & 30 & 1140 & 4.14 & Agree \\
\hline & $42 \%$ & $41 \%$ & $10 \%$ & $4 \%$ & $3 \%$ & 100 & & \\
\hline \multirow{2}{*}{$\begin{array}{l}\text { The activities of the Local refiners have led to } \\
\text { reduction in the number of crops and trees }\end{array}$} & \begin{tabular}{|l|}
438 \\
\end{tabular} & 455 & 165 & 75 & 7 & 1140 & 4.08 & Agree \\
\hline & $38 \%$ & $40 \%$ & $14 \%$ & $7 \%$ & $1 \%$ & 100 & & \\
\hline \multirow{2}{*}{$\begin{array}{l}\text { The major source of water supply is usually } \\
\text { polluted by crude oil waste from local refineries }\end{array}$} & 466 & 441 & 181 & 30 & 22 & 1140 & 4.13 & Agree \\
\hline & $41 \%$ & $38 \%$ & $16 \%$ & $3 \%$ & $2 \%$ & 100 & & \\
\hline \multirow[t]{2}{*}{ Local Refining of Crude oil increases air pollution } & 518 & 438 & 114 & 41 & 29 & 1140 & 3.75 & Agree \\
\hline & $45 \%$ & $38 \%$ & $10 \%$ & $4 \%$ & $3 \%$ & 100 & & \\
\hline \multirow[t]{2}{*}{ People no longer farm or fish because of oil refining } & 414 & 411 & 243 & 58 & 14 & 1140 & 4.01 & Agree \\
\hline & $36 \%$ & $36 \%$ & $21 \%$ & $5 \%$ & $1 \%$ & 100 & & \\
\hline \multirow[t]{2}{*}{ Fish catch has also reduced drastically } & 424 & 410 & 280 & 14 & 12 & 1140 & 4.07 & Agree \\
\hline & $37 \%$ & $36 \%$ & $25 \%$ & $1 \%$ & $1 \%$ & 100 & & \\
\hline \multirow{2}{*}{$\begin{array}{l}\text { The activities of local refining has affected the } \\
\text { quality of air we breathe }\end{array}$} & 412 & 411 & 291 & 17 & 9 & 1140 & 4.05 & Agree \\
\hline & $36 \%$ & $36 \%$ & $26 \%$ & $1 \%$ & $1 \%$ & 100 & & \\
\hline \multirow{2}{*}{$\begin{array}{l}\text { The activities of local refining have negatively } \\
\text { affected security situation of the environment }\end{array}$} & 480 & 418 & 458 & 61 & 23 & 1440 & 4.9 & Agree \\
\hline & $35 \%$ & $31 \%$ & $26 \%$ & $7 \%$ & $1 \%$ & 100 & & \\
\hline \multirow[t]{2}{*}{ The Community drinking water source is polluted } & 466 & 441 & 181 & 30 & 22 & 1140 & 4.13 & Agree \\
\hline & $41 \%$ & $39 \%$ & $16 \%$ & $3 \%$ & $1 \%$ & 100 & & \\
\hline \multirow{2}{*}{$\begin{array}{l}\text { The activities of local refiners have affected the } \\
\text { mangrove resources of the community }\end{array}$} & 467 & 513 & 93 & 53 & 20 & 1146 & 4.2 & Agree \\
\hline & $41 \%$ & $45 \%$ & $8 \%$ & $5 \%$ & $1 \%$ & 100 & & \\
\hline
\end{tabular}

Source: Researchers Computation, 2020

N:B: SA-strongly agree; A-agree, SD-strongly disagree; D-disagree; UND-undecided; WA-weighted average.

Table 3 evaluated the effect of artisanal refineries on economy/ socio-economy development of the study area. $86 \%$ of the respondents agree that, artisanal refineries could be a source of 


\section{Macrothink}

revenue to the government, $12 \%$ of the respondents disagreed and $2 \%$ of the respondents were undecided. Many of the respondents $(83 \%)$ agreed that money generated from artisanal refining has aided the development of the communities' economies, while $16 \%$ of the respondents disagreed. Majority of the respondents (88\%) also agree that artisanal refineries sustains families in the study area, while $11 \%$ disagree. The weighted average of 4.3 affirms that most of the respondents do agree that the financial proceeds off artisanal refineries, sustains families in the study area. The respondents also agreed (79\%) that there is need to allow the growth of artisanal refineries in the area. $20 \%$ of the respondents disagreed. The respondents that disagreed, probably disagreed because of the current environmental consequences that is visible in the area (Beshiru et al., 2018). The respondents disagree (weighted mean of 3.4\%) that the activities of artisanal refiners are healthy to the people and their economy. $63 \%$ of the respondents agree that drilled operation has positive impact on the communities and $34 \%$ of the respondents disagreed. The indication is that the respondents did not entirely agree as a weighted mean of 3.4 was realized.

Furthermore, $84 \%$ of the respondents agreed that there is a difference between conventionally refined PMS and those from the artisanal refiners, and 13\% disagreed. This means that the techniques of production are still primitive, and this makes the products produced substandard. The locals also affirmed that, kerosene derived from artisanal refineries have been responsible for wild fires and domestic fire incidences in the study area. This is hinged on the fact that $86 \%$ of the respondents agreed to the perception, that kerosene derived from artisanal refineries sometimes causes domestic fire accident. The information provided in table 2 points to the fact that, there are aspects of artisanal refineries that benefits the locals, since it provides financial empowerment and security to those who participate in it. However, the effects of it on the economy is malicious since the products therefrom are sub-standard. This could affect engines of those who patronize them. Similarly, the locals' affirmation that, the kerosene got from artisanal refineries are sometimes substandard and responsible for fatal fire accidents, points to the fact that serious economic loss accrue from artisanal refineries too. So that, the primitive methods of crude refining in the study area needs a holistic review, for realization of sustainable economic advancement. 
Table 3. Effects of Artisanal Refineries on the Economy/Socio-economic development

\begin{tabular}{|c|c|c|c|c|c|c|c|c|}
\hline Perceptions & SA & A & D & SD & UND & Total & WA & Decision \\
\hline \multirow[t]{2}{*}{$\begin{array}{l}\text { Artisanal refining can be set as a means of } \\
\text { generating revenue to the government }\end{array}$} & 559 & 429 & 86 & 44 & 22 & 1140 & 4.27 & Agreed \\
\hline & $49 \%$ & $37 \%$ & $8 \%$ & $4 \%$ & $2 \%$ & 100 & & \\
\hline \multirow[t]{2}{*}{$\begin{array}{l}\text { The money generated from artisanal } \\
\text { refining has aided the development } \\
\text { of the communities' economy }\end{array}$} & 453 & 486 & 128 & 57 & 16 & 1140 & 4.14 & Agreed \\
\hline & $40 \%$ & $43 \%$ & $11 \%$ & $5 \%$ & $1 \%$ & 100 & & \\
\hline \multirow[t]{2}{*}{$\begin{array}{l}\text { Artisanal refining is sustaining } \\
\text { families financially }\end{array}$} & 530 & 475 & 95 & 29 & 11 & 1140 & 4.3 & Agreed \\
\hline & $46 \%$ & $42 \%$ & $8 \%$ & $3 \%$ & $1 \%$ & 100 & & \\
\hline \multirow[t]{2}{*}{$\begin{array}{l}\text { There is need to allow the growth of artisanal } \\
\text { refining in the region as modular refineries }\end{array}$} & 439 & 459 & 144 & 84 & 14 & 1140 & 4.07 & Agreed \\
\hline & $39 \%$ & $40 \%$ & $13 \%$ & $7 \%$ & $1 \%$ & 100 & & \\
\hline \multirow{2}{*}{$\begin{array}{l}\text { The activities of artisanal refiners is } \\
\text { healthy to the people and their economy }\end{array}$} & 285 & 437 & 290 & 102 & 26 & 1140 & 3.49 & Disagree \\
\hline & $25 \%$ & $38 \%$ & $25 \%$ & $9 \%$ & $2 \%$ & 100 & & \\
\hline \multirow{2}{*}{$\begin{array}{l}\text { The drilled operation has a positive } \\
\text { impact on the community }\end{array}$} & 285 & 437 & 290 & 102 & 26 & 1140 & 3.42 & Disagree \\
\hline & $25 \%$ & $38 \%$ & $25 \%$ & $9 \%$ & $2 \%$ & 100 & & \\
\hline \multirow{2}{*}{$\begin{array}{l}\text { The drilled operation has a Negative } \\
\text { impact on the community }\end{array}$} & 388 & 417 & 193 & 121 & 21 & 1140 & 3.9 & Agreed \\
\hline & $34 \%$ & $37 \%$ & $17 \%$ & $11 \%$ & $1 \%$ & 100 & & \\
\hline \multirow{2}{*}{$\begin{array}{l}\text { There is a difference between } \\
\text { conventionally refined PMS and } \\
\text { those from the artisanal refiners }\end{array}$} & 548 & 415 & 119 & 39 & 19 & 1140 & 4.25 & Agreed \\
\hline & $48 \%$ & $36 \%$ & $10 \%$ & $3 \%$ & $2 \%$ & 100 & & \\
\hline \multirow{2}{*}{$\begin{array}{l}\text { Local refineries should be legalized and } \\
\text { allowed to operate. }\end{array}$} & 499 & 483 & 62 & 77 & 19 & 1140 & 4.19 & Agreed \\
\hline & $44 \%$ & $42 \%$ & $5 \%$ & $7 \%$ & $2 \%$ & 100 & & \\
\hline \multirow{2}{*}{$\begin{array}{l}\text { Locally made Kerosene results in fire } \\
\text { outbreak with fatal results. }\end{array}$} & 482 & 504 & 70 & 66 & 18 & 1140 & 4.19 & Agreed \\
\hline & $42 \%$ & $44 \%$ & $6 \%$ & $6 \%$ & $2 \%$ & 100 & & \\
\hline \multirow{2}{*}{$\begin{array}{l}\text { There is need to lobby the state/ } \\
\text { national assembly members to } \\
\text { legalize artisanal oil refining. }\end{array}$} & 499 & 483 & 62 & 77 & 19 & 1140 & 4.19 & Agreed \\
\hline & $44 \%$ & $42 \%$ & $5 \%$ & $7 \%$ & $2 \%$ & 100 & & \\
\hline \multirow{2}{*}{$\begin{array}{l}\text { Negative impact of oil refining can be } \\
\text { mitigated by government ownership } \\
\text { of artisanal refining. }\end{array}$} & 459 & 493 & 129 & 36 & 23 & 1140 & 4.16 & Agreed \\
\hline & $40 \%$ & $43 \%$ & $11 \%$ & $3 \%$ & $2 \%$ & 100 & & \\
\hline \multirow{3}{*}{$\begin{array}{l}\text { Private ownership of artisanal } \\
\text { refining and regulation } \\
\text { will moderate artisanal oil refining } \\
\text { in the Niger Delta. }\end{array}$} & 494 & 469 & 82 & 57 & 38 & 1140 & 4.16 & Agreed \\
\hline & & & & & & & & \\
\hline & $43 \%$ & $41 \%$ & $7 \%$ & $5 \%$ & $3 \%$ & 100 & & \\
\hline
\end{tabular}

Source: Researcher's Computation, 2020

N:B: SA-strongly agree; A-agree, SD-strongly disagree; D-disagree; UND-undecided; WA-weighted average.

Table 4 presented the public health implication of artisanal refineries in the study area. $82 \%$ of the respondents agreed that the illegal activities of local refiners affect the health of the 


\section{Ml Macrothink}

people adversely and $11 \%$ disagree. $6 \%$ of the respondents were undecided. Overall, the weighted average of 4.06 affirms that the respondents agree. Similarly, most of the respondents $(74 \%)$ agreed that the rate of cancer has increased in the area. In the same vein many of the respondents (75\%) agree that respiratory disease cases have increase within the communities. Most respondents (71\%), agreed that water pollution from artisanal refineries is a source of sickness in the area, while $25 \%$ of the respondents disagreed. The respondents disagreed that soil pollution is the cause of the increase in sicknesses in the study area. This is because the weighted mean of 3.02 was realized. $79 \%$ of the respondents agreed that consumption of fishes caught from the artisanal refinery polluted steams in the study area is responsible for rise in the number of the sick persons in the study area, while $19 \%$ disagreed. The information derived from table 3 is that, the processing of crude by the artisanal refineries have affected the area's public health. The contamination of the lands, water and air, has a play back effect on the people there. Generally, when water is polluted with heavy metals, fishes in such rivers become sources of heavy metal poisoning. The same can be said of the plants and other edible resources got from the environment. In similar fashion, air pollution has a pervasive effect. It does not only cause new cases of respiratory diseases but can also trigger or exacerbate existing respiratory conditions. In all, the effects of artisanal refineries on the locals cannot be overlooked. It therefore implies that there is urgent need for the modification of approach of the production processes of artisanal refineries.

Table 4. Public Health Implication of Artisanal Refining

\begin{tabular}{|c|c|c|c|c|c|c|c|c|}
\hline Perceptions & $\mathbf{S A}$ & $\mathbf{A}$ & D & SD & UND & Total & WA & Decision \\
\hline \multirow{2}{*}{$\begin{array}{l}\text { The illegal activities of local refiners affects } \\
\text { the health of the people adversely }\end{array}$} & 504 & 430 & 82 & 50 & 74 & 1140 & 4.06 & Agree \\
\hline & $44 \%$ & $38 \%$ & $7 \%$ & $4 \%$ & $6 \%$ & 100 & & \\
\hline \multirow{2}{*}{$\begin{array}{l}\text { The rate of those suffering from cancer has } \\
\text { increased in my community }\end{array}$} & 422 & 426 & 207 & 76 & 9 & 1140 & 4.08 & Agree \\
\hline & $37 \%$ & $37 \%$ & $18 \%$ & $7 \%$ & $1 \%$ & 100 & & \\
\hline \multirow{2}{*}{$\begin{array}{l}\text { The rate of those suffering from respiratory } \\
\text { diseases have increased in my community }\end{array}$} & 521 & 332 & 171 & 102 & 14 & 1140 & 4.1 & Agree \\
\hline & $46 \%$ & $29 \%$ & $15 \%$ & $9 \%$ & $1 \%$ & 100 & & \\
\hline \multirow[t]{2}{*}{ The sickness common in my area is asthma } & 284 & 357 & 157 & 109 & 233 & 1140 & 3.1 & Disagree \\
\hline & $15 \%$ & $31 \%$ & $14 \%$ & $10 \%$ & $20 \%$ & 100 & & \\
\hline \multirow{2}{*}{$\begin{array}{l}\text { Polluted water used is the major sources of } \\
\text { sickness in the area. }\end{array}$} & 429 & 379 & 196 & 90 & 46 & 1140 & 3.9 & Agree \\
\hline & $38 \%$ & $33 \%$ & $17 \%$ & $8 \%$ & $4 \%$ & 100 & & \\
\hline \multirow[t]{2}{*}{ Polluted soil is major source of sickness } & 229 & 379 & 196 & 200 & 136 & 1140 & 3.02 & Disagree \\
\hline & $20 \%$ & $33 \%$ & $17 \%$ & $18 \%$ & $12 \%$ & 100 & & \\
\hline \multirow{2}{*}{$\begin{array}{l}\text { Breathing polluted air is the major } \\
\text { source of sickness }\end{array}$} & 229 & 379 & 196 & 200 & 136 & 1140 & 3.21 & Disagree \\
\hline & $20 \%$ & $33 \%$ & $17 \%$ & $18 \%$ & $12 \%$ & 100 & & \\
\hline \multirow[t]{2}{*}{ Crop produce from polluted farm cause sickness } & 441 & 200 & 150 & 98 & 51 & 1140 & 3.21 & Disagree \\
\hline & $19 \%$ & $22 \%$ & $26 \%$ & $9 \%$ & $4 \%$ & 100 & & \\
\hline \multirow{2}{*}{$\begin{array}{l}\text { Fishes from polluted Rivers causes sickness } \\
\text { when consumed }\end{array}$} & 539 & 365 & 213 & 12 & 11 & 1140 & 4.23 & Agree \\
\hline & $47 \%$ & $32 \%$ & $18 \%$ & $1 \%$ & $1 \%$ & 100 & & \\
\hline \multirow{2}{*}{$\begin{array}{l}\text { The people of the communities are more sick } \\
\text { today than in the era before artisanal refining }\end{array}$} & 300 & 230 & 181 & 240 & 189 & 1140 & 3.04 & Disagree \\
\hline & $26 \%$ & $20 \%$ & $16 \%$ & $21 \%$ & $17 \%$ & 100 & & \\
\hline
\end{tabular}


Source: Researchers Computation, 2020

N:B: SA-strongly agree; A-agree, SD-strongly disagree; D-disagree; UND-undecided; WA-weighted average.

Table 5. Test for significant spatial difference in environmental effects of artisanal refineries

\begin{tabular}{|c|c|c|c|c|c|c|c|c|}
\hline \multicolumn{9}{|c|}{ Test for significant spatial difference in environmental effects of artisanal refineries } \\
\hline \multicolumn{4}{|c|}{ Ranks } & \multirow{2}{*}{$\begin{array}{l}\text { Kruskal-Wallis } \\
\mathrm{H}\end{array}$} & \multirow[t]{2}{*}{ df } & \multirow{2}{*}{$\begin{array}{l}\text { Asymp. } \\
\text { sig }\end{array}$} & \multirow{2}{*}{$\begin{array}{l}\text { Monte } \\
\text { Carlo Sig. }\end{array}$} & \multirow[t]{2}{*}{ Decision } \\
\hline & & $\mathrm{N}$ & Mean Rank & & & & & \\
\hline \multirow[t]{4}{*}{ States } & Delta & 1140 & 814.92 & \multirow[t]{4}{*}{1876.838} & \multirow[t]{4}{*}{2} & \multirow[t]{4}{*}{.000} & \multirow[t]{4}{*}{.000} & \multirow[t]{4}{*}{ Significant } \\
\hline & Bayelsa & 1140 & 1710.50 & & & & & \\
\hline & Rivers & 1140 & 2606.08 & & & & & \\
\hline & Total & 3420 & & & & & & \\
\hline
\end{tabular}

Table 5 presented the Kruskal Wallis test result for the significant spatial difference in environmental effects of artisanal refineries in the study area. The model is significant at $\mathrm{p}<0.05$. This means that significance has been reached. Meaning there is a significant difference in the environmental effects of artisanal refineries in the study area. The mean ranks are indicative of the spatial differences in the environmental effects. In this regard Rivers state is most affected with mean rank of 2606.08 and Delta is the least affected with mean rank of 814.92 .

Table 6 presented the Kruskal Wallis test result for the significant spatial difference in socio-economic effects of artisanal refineries in the study area. The model is significant at $\mathrm{p}<0.05$. This means that significance has been reached. Meaning there is a significant difference in the socio-economic effects of artisanal refineries in the study area. The mean ranks are indicative of the spatial differences in the socio-economic effects of artisanal refineries. In this regard Rivers state is most affected with mean rank of 832.08 and Delta is the least affected with mean rank of 673.92. Reference can be made to the number of heavy duty trucks that load finished products from Rivers and Bayelsa daily.

Table 6. Test for significant spatial difference in socio-economic effects of artisanal refineries

\begin{tabular}{|l|l|l|l|l|l|l|l|l|}
\hline \multicolumn{6}{|l|}{ Test for significant spatial difference in socio-economic effects of artisanal refineries } \\
\hline Ranks & & N & Mean Rank & H & $\begin{array}{l}\text { Asymp. } \\
\text { sig }\end{array}$ & $\begin{array}{l}\text { Monte } \\
\text { Carlo Sig. }\end{array}$ & Decision \\
\hline \multirow{3}{*}{ States } & Delta & 1140 & 673.92 & 1142.231 & 2 & .000 & .000 & Significant \\
\cline { 2 - 4 } & Bayelsa & 1140 & 781.10 & & & & & \\
\cline { 2 - 4 } & Rivers & 1140 & 832.08 & & & & & \\
\cline { 2 - 4 } & Total & 3420 & & & & & & \\
\hline
\end{tabular}


Table 7. Test for significant spatial difference in effects of artisanal refineries on public health

\begin{tabular}{|c|c|c|c|c|c|c|c|c|}
\hline \multicolumn{9}{|c|}{ Test for significant spatial difference in public health effects of artisanal refineries } \\
\hline \multicolumn{4}{|c|}{ Ranks } & \multirow{2}{*}{$\begin{array}{l}\text { Kruskal-Wallis } \\
\mathrm{H}\end{array}$} & \multirow[t]{2}{*}{ df } & \multirow{2}{*}{$\begin{array}{l}\text { Asymp. } \\
\text { Sig }\end{array}$} & \multirow{2}{*}{$\begin{array}{l}\text { Monte } \\
\text { Carlo Sig. }\end{array}$} & \multirow{2}{*}{ Decision } \\
\hline & & $\mathrm{N}$ & Mean Rank & & & & & \\
\hline \multirow[t]{4}{*}{ States } & Delta & 1140 & 435.12 & \multirow[t]{4}{*}{891.004} & \multirow[t]{4}{*}{2} & \multirow[t]{4}{*}{.000} & \multirow[t]{4}{*}{.000} & \multirow[t]{4}{*}{ Significant } \\
\hline & Bayelsa & 1140 & 892.06 & & & & & \\
\hline & Rivers & 1140 & 935.42 & & & & & \\
\hline & Total & 3420 & & & & & & \\
\hline
\end{tabular}

Table 7 presented the Kruskal Wallis test result for the significant spatial difference in public health effects of artisanal refineries in the study area. The model is significant at $p<0.05$. This means that significance has been reached. Meaning there is a significant difference in the public health effects of artisanal refineries in the study area. The mean ranks are indicative of the spatial differences in the public health effects of artisanal refineries. In this regard Rivers state is most affected with mean rank of 935.42 and Delta is the least affected with mean rank of 435.12 .

\section{Discussion}

Respondents claimed that artisanal refineries have reduced the farm lands in the area, through spills and soil pollution. This finding agreed with that of Brakstad et al., (2017). This in turn accounts for the reduced number of persons involved in fishing and farming in the area. Also, the number of crop and trees in the area were affected by artisanal refineries. (Chikere \& Fenibo, 2018; Coderoni \& Perito, 2020), averred that, not only does the spills from the crude methods of artisanal refineries affect land productivity and render crops unproductive, but also the process of artisanal refining include deforestation, thus reduces species of plants in the forests. Furthermore, sources of water supply are polluted by crude oil waste from local refineries. The activities of local refining were also identified to affect the air quality in the study area. Obviously, the locals are suffering from incidences of air pollution in the area. It is also lucid that air pollution from the activities of the artisanal refineries affect the quality of air they breathe there. These findings are in tandem with those of (Dominic, 2016; Elenwo \& Urho, 2017), who averred that the consequences of producing fuel from crude primitively, is pervasive on the environment as it affects the soil, water and atmosphere on one hand, and on the other hand the consumables of man are polluted and consumed by man, thus leading to proliferation in cases of terminal diseases.

The effect of artisanal refineries on economy/ socio-economy development of the study area revealed that, artisanal refineries could be a source of revenue to the government if properly harnessed. The money generated from artisanal refining is thought to aid the development of the communities' economies (host communities), while sustaining families. Thus, many respondents agreed that, there is need for a robust approach to refining locally. However, a few respondents disagreed due to the current environmental consequences that is visible in the area (Elum, Mopipi, \& Henri-Ukoha, 2016; Moses \& Tami, 2014). This is because both those that engage in artisanal refining and persons that reside close to production site are unwell, despite the economic gains. 
However, there is a difference between conventionally refined PMS and those from the artisanal refiners. This means that the techniques of production are still primitive, and this makes the products produced substandard. The locals also affirmed that, kerosene derived from artisanal refineries have been responsible for wild fires and domestic fire incidences in the study area. This is not good for both economy and safety of humans. The information provided points to the fact that, there are aspects of artisanal refineries that benefits the locals, since it provides financial empowerment and security to those who participate in it. However, the effects of it on the economy is malicious since the products therefrom are sub-standard, affects soil and water thus inhibiting agriculture. Also, engines of those who patronize them is constantly under repairs thus putting the vehicle owners at severe economic risks (Naanen, 2019; Naanen \& Tolani, 2014). Similarly, the locals' affirmation that, the kerosene got from artisanal refineries are sometimes substandard and responsible for fatal fire accidents, points to the fact that serious economic loss accrue from artisanal refineries too. So that, the primitive methods of crude refining in the study area needs a holistic review, for realization of sustainable economic advancement.

Also identified herein is that local refining affects the health of the people adversely causing or triggering respiratory disease cases within the communities. Again, artisanal refineries was identified to be a leading cause of source of sickness in the area. The contamination of the lands, water and air, has a play back effect on the people there. Generally, when water is polluted with heavy metals, fishes in such rivers become sources of heavy metal poisoning. The same can be said of the plants and other edible resources got from the environment. In similar fashion, air pollution has a pervasive effect. It does not only cause new cases of respiratory diseases but can also trigger or exacerbate existing respiratory conditions. In all, the effects of artisanal refineries on the locals cannot be overlooked. It therefore implies that there is urgent need for the modification of approach of the production processes of artisanal refineries (Anifowose et al., 2014; Asimiea \& Omokhua, 2013; Atubi, 2015; Ayeni, 2019). The Kruskal-Wallis $\mathrm{H}$ test showed that there is a significant difference in the environmental effects of artisanal refineries $\mathrm{p}<0.05$; there is a significant difference in the socio-economic effects of artisanal refineries in the study area at $p<0.05$ and there is a significant difference in the public health effects of artisanal refineries in the study area at $\mathrm{p}<0.05$.

\section{Conclusion and Recommendation}

The effects of artisanal refineries on the environment, included oil spills on farms, water and air pollution. This in return has affected the economic activities in the study area both negatively (by reducing the number of persons involved in agriculture and fishing) and positively (by engaging youth in production of petroleum products). Also, the health of the people is being affected by the crude methods employed for production of petroleum products. Despite these challenges there are socio-economic gains. This study concludes that appropriate improvement in the production process of petroleum products by artisanal refiners and mitigating the effects of it on environment and health of persons, would be more sustainable. Furthermore, looking at the economic gains that abound in the artisanal refining process, the need for government to meet up with the fuel demand of Nigerians (which currently is not met), and the support to allow the growth of artisanal refining in the region by 
locals, this study concludes that, appropriate authorities of government should develop a law legalizing artisanal refining and license given to interested individuals to operate. This law should be holistic and sustainable both to the environment and human health.

\section{References}

Agoha, E. E. C. (2019). Crude oil in drinking water: Chitosan intervention. In L. Lhotska, L. Sukupova, I. Lackovic, \& G. Ibbott (Eds.), World Congress on Medical Physics and Biomedical Engineering 2018. IFMBE Proceedings, 68/3. Springer, Singapore. https://doi.org/10.1007/978-981-10-9023-3_134

Akpan-Idio, A. U., Ibrahim, A., \& Udo, I. A. (2012). Water quality assessment of okpauku river for drinking and irrigation uses in Yala, Cross river state, Nigeria. Res. J. Environ. Sci., 6, 210-221. https://doi.org/10.3923/rjes.2012.210.221

Albert, O. N., Amaratunga, D., \& Haigh, R. P. (2018). Evaluation of the impacts of oil spill disaster on communities and its influence on restiveness in Niger delta, Nigeria. Proc. Eng., 212, 1054-1061. https://doi.org/10.1016/j.proeng.2018.01.136

Amangabara, G. T., \& Njoku, J. D. (2012). Assessing groundwater vulnerability to the activities of artisanal refining in bolo and environs, ogu/bolo local government area of rivers state; Nigeria. Br. J. Environ. Clim. Change, 2(1), 28.

https://doi.org/10.9734/BJECC/2012/1088

Anejionu, O. C. D., Ahiarammunnah, P.-A. N., \& Nri-ezedi, C. J. (2015). Hydrocarbon pollution in the Niger Delta: geographies of impacts and appraisal of lapses in extant legal framework. Resour. Pol., 45, 65-77. https://doi.org/10.1016/j.resourpol.2015.03.012

Anifowose, B., Lawler, D., van der Horst, D., \& Chapman, L. (2014). Evaluating interdiction of oil pipelines at river crossings using Environmental Impact Assessments: evaluating interdiction of oil pipelines at river crossings. Area, 46, 4-17.

https://doi.org/10.1111/area.12065

Asimiea, A., \& Omokhua, G. (2013). Environmental impact of illegal refineries on the vegetation of the Niger delta, Nigeria. J. Agric. Soc. Res., 13(2), 121-126.

Atubi, A. O. (2015). Effects of oil spillage on human health in producing communities of delta state, Nigeria. Eur. J. Bus. Soc. Sci., 4(8), 14-30.

Ayeni, A. O. (2019). Environmental policies for emergency management and public safety: implementing green policy and community participation. In Emergency and Disaster Management: Concepts, Methodologies, Tools, and Applications. IGI Global. pp. 903-922. https://doi.org/10.4018/978-1-5225-6195-8.ch042

Barenboim, G. M., Borisov, V. M., Golosov, V. N., \& Saveca, A. Y. (2015). New problems and opportunities of oil spill monitoring systems. Proc. Int. Assoc. Hydrol. Sci., 366, 64-74. https://doi.org/10.5194/piahs-366-64-2015

Bebeteidoh, O. L., Pazouki, K., \& Norman, R. (2020). An experimental investigation of the 
physio-chemical properties of locally refined diesel oil. Sustain. Chem. Pharm, 15, 100200. https://doi.org/10.1016/j.scp.2019.100200

Beshiru, A., Okareh, O. T., Chigor, V. N., \& Igbinosa, E. O. (2018). Assessment of water quality of rivers that serve as water sources for drinking and domestic functions in rural and pre-urban communities in Edo North, Nigeria. Environ. Monit. Assess., 190, 387. https://doi.org/10.1007/s10661-018-6771-7

Brakstad, O. G., Lofthus, S., Ribicic, D., \& Netzer, R. (2017). Biodegradation of petroleum oil in cold marine environments. Psychrophiles: from Biodiversity to Biotechnology. Springer, Cham. pp. 613-644. https://doi.org/10.1007/978-3-319-57057-0_27

Chen, J., Zhang, C., Wang, Y., \& Xu, W. (2020). A longitudinal study of inferiority impacting on aggression among college students: the mediation role of cognitive reappraisal and expression suppression. Pers. Indiv. Differ., 157, 109839.

https://doi.org/10.1016/j.paid.2020.109839

Chikere, C. B., \& Fenibo, E. O. (2018). Distribution of PAH-ring hydroxylating dioxygenase genes in bacteria isolated from two illegal oil refining sites in the Niger Delta, Nigeria. Sci. African, 1, e00003. https://doi.org/10.1016/j.sciaf.2018.e00003

Coderoni, S., \& Perito, M. A. (2020). Sustainable consumption in the circular economy. An analysis of consumers' purchase intentions for waste-to-value food. J. Clean. Prod., 252, 119870. https://doi.org/10.1016/j.jclepro.2019.119870

Dominic, A. A. (2016). Impact of illegal oil business and Nigeria economy: the experience of crude oil theft, bunkering and pipeline vandalism in the 21st century. Int. J. Adv. Acad. Res. Arts Human. Educ., 2(8).

Elenwo, E., \& Urho, C. (2017). Challenges and prospects of enforcement of environmental laws in port harcourt metropolis rivers state, Nigeria. Br. J. Appl. Sci. Technol., 19, 1-29. https://doi.org/10.9734/BJAST/2017/31447

Elum, Z. A., Mopipi, K., \& Henri-Ukoha, A. (2016). Oil exploitation and its socioeconomic effects on the Niger Delta region of Nigeria. Environ. Sci. Pollut. Control Ser., 23(13), 12880-12889. https://doi.org/10.1007/s11356-016-6864-1

Moses, O., \& Tami, A. G. (2014). Perspective: the environmental implications of oil theft and artisanal refining in the Niger delta region. Asian Rev. Environ. Earth Sci., 1(2), 25-29.

Naanen, B. (2019). When extractive governance fails: oil theft as resistance in Nigeria. Extract. Indust. Soc., 6(3), 702-710. https://doi.org/10.1016/j.exis.2019.03.019

Naanen, B., \& Tolani, P. (2014). Private gain, public disaster: social context of illegal oil bunkering and artisanal refining in the Niger Delta. Port Harcourt: Niger Delta and Environmental Relief Foundation Pub.

Nkemakolem, S. (2018). Navy Destroys Illegal Refineries in Bayelsa. [Online] Available: https://punchng.com/navy-destroys-illegal-refineries-in-bayelsa 


\section{Macrothink}

Environmental Management and Sustainable Development

ISSN 2164-7682

2021, Vol. 10, No. 3

Nwaejije, E. C., Hamidu, I., \& Obiosio, E. O. (2017). Early to middle miocene sequence stratigraphy of well-5 (OML 34), Niger Delta, Nigeria. J. Afr. Earth Sci., 129, 519-526. https://doi.org/10.1016/j.jafrearsci.2017.01.026

\section{Copyright Disclaimer}

Copyright for this article is retained by the author(s), with first publication rights granted to the journal.

This is an open-access article distributed under the terms and conditions of the Creative Commons Attribution license (http://creativecommons.org/licenses/by/4.0/). 